\title{
Understanding museum vacationers' eco-friendly decision-making process: Strengthening the VBN framework
}

\author{
Authors: H. Han, H. Olya, S. Cho \& W. Kim
}

\begin{abstract}
In the present research, the process of vacationers' pro-environmental decision formation for environmentally responsible museums was examined. This research employed and broadened the value-belief-norm theory, using satisfaction with green product use, green trust, and frequency of past behavior for green product use as predictors. A structural equation modeling was utilized for modeling comparisons and hypothesis testing. A measurement model tested using the data gathered at museums was found to satisfactorily fit to the data. Newly integrated constructs significantly improved the prediction power of the theory. In addition, results of the structural equation modeling generally supported the proposed relationships. Moreover, a salient role of moral norm was identified. As expected, new environmental paradigm, awareness of consequences, ascribed responsibility, and moral norm played an important mediating role. A parsimonious model with greater prediction power than the original value-belief-norm theory was produced through modeling comparisons and the process of testing relationships among research variables. Our results offer a sufficient understanding of vacationers' pro-environmental intention for eco-friendly museums.
\end{abstract}

Keywords: Value-belief-norm theory, museum vacationers, satisfaction with green product use, green trust, frequency of past behavior for green product use 


\section{Introduction}

In the museum industry, a steadily growing phenomenon is customer demand for an environmentally responsible establishment and evidence of customers' ecologically thoughtful behaviors when visiting a museum (Han \& Hyun, 2017). Sustainability in

museums has thus become an increasingly essential issue receiving a great deal of attention from museum practitioners, visitors, and the general public (Brophy \& Wylie, 2008; Wylie \& Brophy, 2008). Environmentally responsible museums integrate concepts of sustainability/green into their facilities, operations, programming, designs, and exhibits (Brophy \& Wylie, 2006; Byers, 2008). The terms “environmentally responsible", "green”, "sustainable", and "eco-friendly" include similar meanings, and thus these words are frequently used interchangeably (Han, 2015). In an increasingly eco-conscious consumer market, such endeavors of greening the museum is regarded to be an efficient strategy for gaining a competitive advantage/benefit over other types of rival holiday-leisure/tourism products (Han \& Hyun, 2017).

Social psychology theories for the past decades have continuously advanced our knowledge and understanding of one's pro-social/pro-environmental behaviors (Han et al., 2016; Van Riper \& Kyle, 2014). The value-belief-norm theory comprising value orientations and new environmental paradigm along with the variables originally established in Schwartz's (1977) norm activation model (i.e., awareness of consequences, ascription of responsibility, and moral norm) was specifically designed to unearth an environmental facet of individuals’ pro-social behaviors (López-Mosquera \& Sánchez, 2012; Stern, 2000; Stern et al., 1999). The basic assumption of the value-belief-norm theory is that an individual's proenvironmental intention/behavior is triggered by a moral norm, and this moral obligation is activated by the sequential procedure of values (biospheric, altruistic, and egoistic) - new environmental paradigm - awareness of consequences - ascription of responsibility (Han, 
2015; López-Mosquera \& Sánchez, 2012; Stern, 2000; Van der Werff \& Steg, 2016).

Because of its high explanatory ability for environmentally responsible decision/behavior, the value-belief-norm model has been extensively utilized in various contexts of environmental behaviors (Fornara et al., 2016; Van Riper \& Kyle, 2014).

However, despite the broad application of the value-belief-norm framework for proenvironmental behavior, the theory's prediction power has been frequently questioned (Choi et al., 2015; Klöckner, 2013; Fornara et al., 2016; Han, 2015). In order to gain a broader understanding of one's environmentally responsible decision-making procedure and action in a particular environmental context, broadening the value-belief-norm framework is a necessary process (Klöckner, 2013; Han, 2015; Oreg \& Katz-Gerro, 2006). Moreover, to date, how some core variables within the value-belief-norm framework (i.e., awareness of consequences, ascription of responsibility, and moral norm) are associated with each other are somewhat unclear (Hopper \& Nielsen, 1991; Vining \& Ebreo, 1992). While researchers generally use them as sequential variables, some researchers have asserted no relation between awareness of consequences and ascribed responsibility in activating moral norm (Han, 2014). That is, the role of these variables within the theory needs to be more clearly identified.

Furthermore, in a hospitality/tourism product consumption situation, Han and Yoon (2015) insisted on the importance of one's satisfaction with green product use, and Choi et al. (2015) asserted the criticality of green trust in explicating a customer's pro-environmental decision formation. Additionally, Kim and Han (2010) and Han et al. (2010) claimed the importance of frequency of past behavior for green product use. Nonetheless, little research has examined the role of these variables concurrently. In addition, no research effort has been made to expand the value-belief-norm framework by including these vital concepts and to 
investigate how these variables are related to the established variables of the value-beliefnorm theory.

In order to fill these existing research gaps discussed above, this study developed the following research objectives:

1) Build a theoretical model of museum vacationers' eco-friendly intention by integrating satisfaction with green product use, green trust, and frequency of past behavior for green product use into the value-belief-norm framework in the environmentally responsible museum context (development of the extended valuebelief-norm theory).

2) Compare this extended model to the original theory for the identification of its superior capability in predicting museum vacationers' pro-environmental intention (modeling comparison).

3) Unearth the relative strength of research variables in determining intention (identification of relative importance).

4) Assess the mediating impact of study variables on vacationers' intention formation (assessment of mediating impact).

In the following section, a thorough literature review is provided. Subsequently, the methodology used in the present study along with the data analysis results and findings are reported. Lastly, discussion and implications of the research is presented.

\section{Literature review}

\section{Environmentally responsible museums}


The sustainable museum movement was initiated in children's museums due to the concerns for youthful visitors' health (Brophy \& Wylie, 2008; Byers, 2008). Specifically, the use of the harmful materials and chemicals on facilities/structures for young visitors became a high apprehension for their parents and museum operators (Brophy \& Wylie, 2008). A variety of museums (science museums, zoos, maritime museums, history museum, art museum, etc.) have quickly followed the environmentally responsible movement of children's museums by adopting green initiatives. An increasing number of museums are now certified from the Leadership in Energy and Environmental Design (LEED).

Unlike museums that are little engaged in eco-friendly practices (Sutter, 2006), environmentally responsible museums promote sustainable practices to vacationers through signage, programming, classes, events, or websites with the goal to help them learn about green activities at the museum and then be able to implement such sustainable practices into their everyday lives. There is some evidence to suggest that a sustainable museum also motivates employees to actively engage in green behaviors and make environmentally responsible choices within their operations and at their home (Byers, 2008). In environmentally responsible museums, efforts for recycling, energy conservation, waste reduction, improved sustainability through products/procedures, and sustainability education are common (Brophy \& Wylie, 2006; Byers, 2008; Wylie \& Brophy, 2008).

\section{Value-belief-norm theory}

The norm activation model contains three core variables determining pro-environmental decision/behavior, namely awareness of consequences, ascription of responsibility, and moral norm (Han, 2014). Awareness of consequences indicates individuals' consciousness level about undesirable consequences for valued objects when not taking actions proenvironmentally (Schwartz, 1977). Ascription of responsibility, on the other hand, refers to 
individuals' own feeling of responsibility for such adverse consequences of not performing behaviors pro-environmentally (De Groot and Steg, 2009). Within the norm activation framework, these cognitive concepts of beliefs activate individuals' moral norm (De Groot \& Steg, 2007). This moral norm refers to individuals' feeling of personal moral obligation whether or not to engage in environmentally responsible actions (Han, 2015).

While the norm activation model has been broadly utilized in the domain of prosocial behavior, the value-belief-norm theory has been extensively employed particularly in the domain of pro-environmental behavior. The value-belief-norm theory (Stern, 2000; Stern et al., 1999) was the extension of the norm activation theory. In order to more thoroughly and sufficiently explicate one's environmentally-relevant decision formation and behavior, in this theory, several key variables that are critical in environmental behavior (i.e., three value orientations [biospheric, altruistic, and egoistic] and new environmental paradigm) were integrated into the norm activation framework. In particular, the value-belief-norm theory was a broadened version of the sequential mediator framework of Schwartz's theory with an inclusion of value orientations and new environmental paradigm (Fornara et al., 2016).

The value-belief-norm theory established the relationships among personal values, beliefs (new environmental paradigm, awareness of consequences, and ascription of responsibility), moral norm, and environmental intention/behavior (Fornara et al., 2016; Stern et al., 1999). Reflecting the sequential interpretation of the norm activation model, according to this theory, individuals' environmentally responsible decisions/behaviors are formed through the casual value-belief-norm process (biospheric, altruistic, and egoistic values $\rightarrow$ new environmental paradigm awareness of consequences ascription of responsibility moral norm pro-environmental intention/behavior) (Oreg \& Katz-Gerro, 2006). The choice of adopting or not adopting pro-environmental behavior (e.g., whether or not to 
choose an eco-friendly hospitality/tourism product over a conventional product) comprises a pro-social norm activation process as postulated in the value-belief-norm theory (Han, 2015).

According to Schwartz (1992), personal values refer to "the criteria that people use to select and justify actions and to evaluate people (including the self) and events" (p. 1). Such value orientations include biospheric, altruistic, and egoistic dimensions (Stern et al., 1993). An individual with high biospheric value bases their decision/behavior on the benefits/costs for the biosphere/ecosystem; one with high altruistic value places emphasis on the benefits/costs for other people; and, an individual with high egoistic value more heavily focuses on personal benefits/costs (Choi et al., 2015; Stern et al., 1999). New environmental paradigm is one's general pro -environmental beliefs (Dunlap \& Van Liere, 1978; Dunlap et al., 2000; Fornara et al., 2016). Stern (2000) described this variable as a propensity of performing behaviors with eco-friendly intent. Within the value-belief-norm theory, this variable is influenced by three values and supports awareness of consequences (Van Riper \& Kyle, 2014).

H1: Biospheric value has a positive influence on new environmental paradigm. H2: Altruistic value has a positive influence on new environmental paradigm. H3: Egoistic value has a positive influence on new environmental paradigm. H4: New environmental paradigm has a positive influence on awareness of consequences.

H5: Awareness of consequences has a positive influence on ascription of responsibility.

H6: Ascription of responsibility has a positive influence on moral norm. H7: Moral norm has a positive influence on pro-environmental intention. 


\section{Theory broadening}

Theory broadening using the pro-social/pro-environmental model has been widely attempted by many researchers in a variety of environmental contexts (e.g., Bamberg \& Möser, 2007; Choi et al., 2015; Fornara et al., 2016; Han, 2014; Han \& Yoon, 2015; Klöckner \& Matthies, 2004; Milfont et al., 2010; Stern, 2000; Zhang et al., 2013). These researchers have demonstrated that a pro-social/pro-environmental theory better accounted for individuals' eco-friendly decision formation and behavior when incorporating new variables that are crucial in a specific sector or altering the links established in the original theory. These researchers' efforts have contributed to increasing the competency of the original theory, leading to the theory's greater prediction power in a given sector.

Numerous researchers in diverse environmental contexts have asserted the criticality of satisfaction with eco-friendly consumption (e.g., Asgharian et al., 2012; Chang \& Fong, 2010; Chen et al., 2011; Okello \& Yerian, 2009), green trust (e.g., Chen, 2010; Chen, 2013; Chen \& Chang, 2013; Choi et al., 2015), and frequency of past behavior (e.g., Bamberg et al., 2007; Han et al., 2010; Song et al., 2012) in implicitly explaining individuals' proenvironmental/pro-social decision formation and behavior. An integration of these crucial variables into the original value-belief-norm theory would result in the increased sufficiency and precise comprehension of customers' pro-environmental intention formation and behavior. Existing studies on the partial incorporation of these essential concepts have indeed offered a superior accountability of the theory for customers' pro-environmental intention

(e.g., Bamberg et al., 2007; Choi et al., 2015; Song et al., 2012). Rooting our conceptual framework in the value-belief-norm theory allows us to integrate vital concepts in the environmental behavior (i.e., satisfaction with green product use, green trust, and frequency of past behavior for green product use) in illuminating vacationers' eco-friendly intention formation for environmentally responsible museums. 
Figure 1 shows the theoretical model of this study. The model contains a total of 11 research constructs. As indicated earlier, eight variables are the original constructs within the value-belief-norm theory, while three variables are new constructs integrated into the theory. Our conceptual framework comprises a total of ten research hypotheses.

\section{(Insert Figure 1)}

\section{Satisfaction with green product use}

For the past few decades, satisfaction has been believed to be one of the most practical and theoretical issues for most consumer researchers and marketers (Chang \& Fong, 2010; Jamal, 2004). According to Oliver (1997), satisfaction is "a judgment that a product/service feature, or the product or service itself, provided (or is providing) a pleasurable level of consumptionrelated fulfillment, including levels of under- or over-fulfillment" (p. 13). Satisfaction in this definition is viewed as a fulfillment of individuals' consumption-related goals as experienced and depicted by themselves (Oliver, 2006). In line with these definitions, satisfaction with green product use in the present research refers to an evaluation that consuming a green product and its features offer a high/low level of consumption-related fulfillment, and the outcomes of such consumption meets the needs and goals of customers (Chang \& Fong, 2010).

\section{Impact of satisfaction with green product use}

Multiple studies in an environmentally responsible consumption context have demonstrated that individuals' purchasing intention is significantly influenced by satisfaction (Chang \& Fong, 2010; Chen, 2013; Han \& Ryu, 2012; Kang \& Hur, 2012). In these studies, satisfaction was one of the most influential constructs in determining their purchase intention. Kang and 
Hur (2012) also identified that individuals' green satisfaction along with green trust is vital in forming their green brand loyalty. Satisfaction is an important determinant of long-term customer behavior. When customers have a satisfying experience with a green product/service, they form a high level of purchase intention for environmentally responsible products/services (Han \& Ryu, 2012). Chen (2013) also empirically demonstrated that patrons' satisfaction with a green product exerted a significant influence on their green loyalty. Moreover, Asgharian et al. (2012) asserted that customer satisfaction with green products along with its quality significantly elicit their level of loyalty for green products.

Based on these evidences, this study proposed that museum customers' satisfactory experience with green product use triggers their intention to visit an environmentally responsible museum.

H8: Satisfaction with green product use has a positive influence on proenvironmental intention.

\section{Green trust}

The term "trust" has long been regarded to be a vital variable in elucidating customers' purchase/post-purchase decision-making process and behavior. Researchers in consumer behavior and marketing agree that the key aspects of trust comprise confidence, integrity, and reliability (Mayer et al., 1995). Moorman et al. (1993) conceptualized trust as "a willingness to rely o an exchange partner in whom one has confidence" (p. 82). Morgan and Hunt (1994) defined trust as "existing when one party has confidence in an exchange partner's reliability and integrity" (p. 23). In line with these definitions, Chen (2010) described green trust as "a willingness to depend on a product, service, or brand based on the belief or expectation resulting from its credibility, benevolence, and ability about its environmental performance" 
(p. 309). Supporting this conceptualization, Choi et al. (2015) identified that the value-beliefnorm framework better explicates guests' eco-friendly intention when green trust is involved.

\section{Impact of green trust}

Once individuals form trust, their perceived risk and uncertainty related to a purchase of product/service decrease whereas their positive purchasing decision/behavior for the product/service increases (Sparks \& Browning, 2011). According to Martínez \& Rodríguez del Bosque (2013) and Morgan and Hunt (1994), trust is closely associated with the behavioral outcomes; individuals' willingness to accept risk/uncertainty while believing that the outcomes will meet their expectations eventually results in the increased behavioral intention. Similarly, in a service consumption situation, patrons who highly trust the provider are more likely to feel assured and be confident about the services they receive (Parasuraman et al., 1985). Green trust along with green satisfaction significantly increases their level of loyalty for eco-friendly products (Chen, 2013). Given these indications and evidences, it can be posited that museum customers' green trust induces their intention to visit an environmentally responsible museum.

H9: Green trust has a positive influence on pro-environmental intention.

\section{Frequency of past behavior}

Past behavior has been frequently discussed and employed in existing studies employing social psychology theories (Han et al., 2010; Perugini \& Bagozzi, 2001; Song et al., 2012). This concept has been often utilized as a form of frequency of past behavior (Han et al., 2010; Song et al., 2012). Past behavior can be described as the repetition of individuals' behavior in the past (Ajzen, 2002; Sommer, 2011). Consistently, in the present study, 
frequency of past behavior for green product use refers to the frequency of repetition of customers' use/purchase of environmentally friendly products.

\section{Impact of frequency of past behavior}

For the past two decades, the impact of the frequency of past behavior as a direct predictor of behavioral intention has drawn attention in the existing literature (e.g., Han et al., 2010; Sommer, 2011; Song et al., 2012). Specifically, in a hospitality setting, Han et al. (2010) identified the significant impact of the frequency of past behavior on guests' intention to visit a sustainable lodging operation. Their finding also verified the significant increase in predictive ability of a socio -psychological theory when involving this variable. In addition, Sommer (2011), in his research about human information processing, identified the particular importance of past behavioral frequency and found it as a critical direct predictor of intention. Moreover, when examining the influence of environmental-friendly perceptions on travelers' decision formation, Song et al. (2012) empirically demonstrated that frequency of past behavior exerts a significantly direct influence on travelers' behavioral intention. Although the original framework of the value-belief-norm theory does not comprise individuals' past behavior, numerous research as discussed above has proven that frequency of past behavior is an essential determinant of intention. Given this, this study posited that vacationers' frequency of past behavior for green product use significantly increases their proenvironmental intention for sustainable museum operation.

H10: Frequency of past behavior of green product use has a positive influence on pro-environmental intention.

\section{Methods}




\section{Measures}

Measurement items used in the present research were employed from the previous studies (Ajzen, 1991; Bamberg et al., 2007; Chen, 2010; Cordano et al., 2011; De Groot \& Steg, 2007; De Groot et al., 2007; Han, 2015; Hwang \& Hyun, 2017; Jani \& Han, 2014; Morgan \& Hunt, 1994; Oliver, 1997; Onwezen et al., 2013; Perugini \& Bagozzi, 2001; Stern et al., 1999). Multiple items were used for the assessment of all constructs. In addition, a sevenpoint scale was utilized. Four, three, and four items were utilized to measure biospheric, altruistic, and egoistic values, respectively. New environmental paradigm was evaluated with five items. Four items were used to assess awareness of consequences. Ascription of responsibility was evaluated with three measurement items. Moral norm was assessed with four items. Three items were used to evaluate satisfaction with green product use. Green trust was assessed with three items. Two items were utilized to measure frequency of past behavior for green product use. Pro-environmental intention was assessed with three items. The survey questionnaire including these measures, detailed description about environmentally responsible museums, and questions for demographic information, were pretested by twelve hospitality and tourism academics whose visitation to museums is frequent in order to improve the content validity. Based on the feedback of these academics, the original questionnaire was slightly altered. Moreover, this revised questionnaire was carefully examined again by experts in tourism academia and industry. An improvement on the questionnaire was made through these processes. All measurement items utilized in the present research are exhibited in Appendix (available as supplementary material in the online version of the article).

\section{Data collection procedure}


A field survey with a non-probability convenience sampling approach was used in order to collect the data. The survey was at eight major museums in a metropolitan city, South Korea. The data collection at these museums took about two weeks (i.e., the first two weeks of October 2015). Well-trained students acted as surveyors. The selected museums (e.g., art museums, war museums, contemporary art museums, history/cultural museums, and a palace museum) are considered to be the major museums in South Korea. These museums are in general known to perform pro-environmental management, following eco-friendly principles and guidelines. These students approached museum vacationers who were resting in cafés/restaurants within the museum and rest areas within the museum, and asked the vacationers' willingness for survey participation. Only those visitors who had visited the museum within the last one year, excluding this visit, and had gone to the museum before resting at the café, restaurant, or rest areas were requested to participate in the survey. Once the vacationers agreed to participate in the survey, a detailed explanation about our research was given. In addition, all vacationers were requested to carefully read the description of the environmentally responsible museums and the introductory letter before filling out the questionnaire. All vacationers voluntarily participated in the survey. For the increase of response rate and usable responses, the participants were requested to return the completed questionnaire onsite. Among 600 survey questionnaires disseminated, a total of 429 usable questionnaires were obtained after eliminating incomplete/unusable responses and extreme outliers (Usable response rate $=71.5 \%$ ). Prior to analyzing the data and testing the research framework, the values of kurtosis and skewness were checked. Our examination revealed no significant kurtosis and skewness problems. Thus, these 429 cases were utilized to analyze the data.

\section{Sample characteristics}


Sample characteristics were investigated. In particular, a total of $44.8 \%$ of the respondents were male museum vacationers whereas $54.9 \%$ were female vacationers. All respondents' average age was 30.5 years. The respondents' frequency of museum visits within the last one year was 2.18 times on average. Their frequency of museum visits within the last three years was about 6.54 times. A majority of the respondents are highly educated. About $66.7 \%$ of the participants indicated that they are university graduates; and $14.1 \%$ indicated that they have a graduate degree. Two-year college graduates and high school graduates (or less) were only

$8.5 \%$ and $10.8 \%$, respectively. Regarding the participants' annual incomes, the income between $\$ 40,000$ and $\$ 84,999$ was reported by $44.3 \%$ of the respondents. The incomes under $\$ 39,999$ and over $\$ 85,000$ were reported by $37.0 \%$ and $18.6 \%$ of the respondents, respectively.

\section{Results}

\section{Reliability and construct validity assessment}

The measurement model using a confirmatory factor analysis was generated to test composite reliability and construct validity. AMOS 20 was used for the confirmatory factor analysis.

The fit statistics of the model was satisfactory $\left(\chi^{2}=1515.28, d f=683, \chi^{2} / d f=2.22, p<.001\right.$, $\mathrm{RMSEA}=.053, \mathrm{CFI}=.92, \mathrm{IFI}=.93, \mathrm{TLI}=.92)$. Composite reliability values ranged from .75 to .94 (see Table 1). All values were more than Hair et al.'s (2010) recommended threshold of .70, thus indicating an adequate level of reliability for the research variables. Average variance extracted was then calculated. The values ranged from .51 to .85 . These values were all above the cutoff of .50 (Hair et al., 2010). In addition, all factor loadings (standardized) were significant at .01 level. These findings indicated the acceptable level of convergent validity. Subsequently, these average variance extracted values were compared to correlations between a pair of research variables in order to demonstrate discriminant validity 
(Fornell \& Larcker, 1981). As illustrated in Table 1, an adequate level of discriminant validity was confirmed as any pair of correlation was greater than the average variance extracted values.

\section{(Insert Table 1)}

\section{Goodness of the structural model fit and modeling comparisons}

Structural equation modeling was conducted. The model comprised a satisfactory fit to the data $\left(\chi^{2}=1721.10, d f=713, \chi^{2} / d f=2.41, p<.001, \mathrm{RMSEA}=.057, \mathrm{CFI}=.91, \mathrm{IFI}=.91, \mathrm{TLI}\right.$ $=.90)$. This extended model was then compared to the original value-belief-norm theory, which also includes an acceptable model fit $\left(\chi^{2}=1272.27, d f=454, \chi^{2} / d f=2.80, p<.001\right.$, RMSEA $=.065, \mathrm{CFI}=.90, \mathrm{IFI}=.90, \mathrm{TLI}=.89)$. As shown in Table 2, chi-square test revealed that the proposed extended value-belief-norm model was significantly better than the original theory $\left(\Delta \chi^{2}=448.83, d f=259, \mathrm{p}<.01\right)$. In addition, the prediction power of the extended model for museum vacationers' pro-environmental intention $\left(\mathrm{R}^{2}=.45\right)$ was significantly stronger than the original value-belief-norm theory $\left(\mathrm{R}^{2}=.41\right)$. Thus, although the difference of $\mathrm{R}^{2}$ between the proposed model and the original value-belief-norm theory slightly differed, this evidence indicates that our proposed theoretical model is somewhat superior to the original theory. Table 3 and Figures 2, and 3 include the details related to the findings from the structural equation modeling for the original value-belief-norm theory and the proposed model.

\section{(Insert Table 2) \\ (Insert Table 3) \\ (Insert Figure 2)}




\section{(Insert Figure 3)}

Nonetheless, modification indices indicated that the direct links from satisfaction with green product use, green trust, and frequency of past behavior for green product use to moral norm and the path from satisfaction to green trust need to be added to improve the fit. These direct linkages suggested by modification indices can be theoretically justified. Some researchers indicated that satisfaction, trust, and past behavior are significant contributors to eliciting moral obligation (Han \& Ryu, 2012; Han et al., 2010; Kang \& Hur, 2012; Teraji, 2009), and that this satisfaction is also identified to be a direct driving force of trust (Kang \& Hur, 2012; Morgan \& Hunt, 1994). Therefore, the structural model was re-estimated by incorporating these four direct paths (i.e., satisfaction with green product use moral norm, green trust moral norm, frequency of past behavior for green product use moral norm, and satisfaction with green product use green trust). The modifications made by integrating such links improved the model fit $\left(\chi^{2}=1698.58, d f=714, \chi^{2} / d f=2.38, p<.001\right.$, RMSEA $=$ $.057, \mathrm{CFI}=.91, \mathrm{IFI}=.91, \mathrm{TLI}=.90)$. However, while the paths from satisfaction to moral norms, from frequency of past behavior to moral norm, and from satisfaction to green trust were significant $(\mathrm{p}<.01)$, the linkage between green trust and moral norm was insignificant $(\mathrm{p}>.05)$.

Thus, after the estimation of the revised model, non-significant paths $(\mathrm{p}>.05)$ (i.e., green trust moral norm, altruistic value new environmental paradigm) were excluded in order to construct a parsimonious final model. The model was refit after the exclusion of the paths. As reported in Table 2, the final model provided a satisfactory fit to the data $\left(\chi^{2}=\right.$ 1492.23, $\left.d f=574, \chi^{2} / d f=2.60, p<.001, \mathrm{RMSEA}=.061, \mathrm{CFI}=.91, \mathrm{IFI}=.91, \mathrm{TLI}=.90\right)$.

This final model included a more sufficient prediction power for intention than the original value-belief-norm model $\left(\Delta \chi^{2}=228.87, d f=139, \mathrm{p}<.01\right)$ and the proposed model $\left(\Delta \chi^{2}=\right.$ 
219.96, $d f=120, \mathrm{p}<.01)$. Specifically, this model accounted for the $49.0 \%$ of the total variance in pro-environmental intention. The results of the final model are exhibited in Table 3 and Figure 4. This final model was remained for hypotheses testing and further analyses.

\section{(Insert Figure 4)}

\section{Hypothesis testing}

The hypothesized impact of biospheric, altruistic, and egoistic values on new environmental paradigm was tested. As expected, both biospheric $(\beta=.56, \mathrm{p}<.01)$ and egoistic $(\beta=.17, \mathrm{p}<$ $.01)$ values were significantly and positively related to new environmental paradigm, thus supporting hypotheses 1 and 3. Yet, the altruistic value - new environmental paradigm linkage was not significant (this path was excluded when constructing the final parsimonious model). Thus, hypothesis 2 was not supported. The hypothesized relationships among new environmental paradigm, awareness of consequences, ascription of responsibility, moral norm, and pro-environmental intention were evaluated. Results of the structural equation modeling revealed that the new environmental paradigm - awareness of consequences link ( $\beta$ $=.31, \mathrm{p}<.01)$, the awareness of consequences - ascription of responsibility link $(\beta=.60, \mathrm{p}<$ $.01)$, the ascription of responsibility - moral norm link $(\beta=.34, \mathrm{p}<.01)$, and the moral norm - pro-environmental intention link $(\beta=.48, \mathrm{p}<.01)$ were all positive and significant. These findings supported hypotheses 4, 5, 6, and 7 .

The hypothesized influence of satisfaction with green product use, green trust, and frequency of past behavior for green product use on pro-environmental intention was evaluated. As expected, findings from the structural equation modeling indicated that the impact of satisfaction with green product use $(\beta=.13, \mathrm{p}<.05)$, green trust $(\beta=.13, \mathrm{p}<.05)$, and frequency of past behavior for green product use $(\beta=.17, \mathrm{p}<.01)$ on pro-environmental 
intention was positive and significant. These results supported hypotheses 8,9 , and $10 . \mathrm{R}^{2}$ values for moral norm, ascription of responsibility, awareness of consequences, green trust, and new environmental paradigms were 49, 36, 10, 32, and 35, respectively. In addition, the added links from satisfaction with green product use to moral norm $(\beta=.23, p<.01)$, from satisfaction to green trust $(\beta=.57, \mathrm{p}<.01)$, and from frequency of past behavior for green product use to moral norm $(\beta=.31, \mathrm{p}<.01)$ were all positive and significant. The details regarding hypothesis testing are exhibited in Table 3 and Figure 4.

\section{(Insert Figure 2)}

The indirect impact of research variables was examined. Our results indicated that ascribed responsibility significantly affected pro-environmental intention indirectly through moral norm $(\beta \mathrm{AR} \rightarrow \mathrm{MN} \rightarrow \mathrm{PI}=.16, \mathrm{p}<.05)$; awareness of consequences significantly influenced moral norm through ascription of responsibility $(\beta \mathrm{AC} \rightarrow \mathrm{AR} \rightarrow \mathrm{MN}=.20, \mathrm{p}<.01)$; and, new environmental paradigm significantly affected ascription of responsibility indirectly through awareness of consequences $(\beta \mathrm{NEP} \rightarrow \mathrm{AC} \rightarrow \mathrm{AR}=.19, \mathrm{p}<.01)$. In addition, our findings showed that biospheric value included a significant indirect influence on awareness of consequences $(\beta \mathrm{BV} \rightarrow \mathrm{NEP} \rightarrow \mathrm{AC}=.17, \mathrm{p}<.01)$. Moreover, satisfaction $(\beta \mathrm{SGPU} \rightarrow \mathrm{MN} \& \mathrm{GT} \rightarrow \mathrm{PI}$ $=.19, \mathrm{p}<.01)$ and frequency of past behavior $(\beta$ FPBGPU $\rightarrow \mathrm{MN} \rightarrow \mathrm{PI}=.15, \mathrm{p}<.05)$ included a significant indirect influence on pro-environmental intention. These findings supported a significant mediating role of research constructs. Subsequently, the total impact of variables on pro-environmental intention was assessed. As shown in Table 3, the magnitude of the impact of moral norm $(\beta=.48, \mathrm{p}<.01)$ on pro-environmental intention was the greatest among research constructs, followed by satisfaction with green product use $(\beta=.32, \mathrm{p}<.01)$, frequency of past behavior for green product use $(\beta=.32, \mathrm{p}<.01)$, ascription of 
responsibility $(\beta=.16, \mathrm{p}<.05)$, green trust $(\beta=.13, \mathrm{p}<.05)$, and awareness of consequences $(\beta=.10, \mathrm{p}<.05)$. The total impact of other variables on intention was not significant ( $\mathrm{p}$ $>.05)$.

A series of constraint tests were conducted to further validate the addition of new variables and examine the differential contributions to increasing pro-environmental intention among the direct contributors of intention (satisfaction with green product use, green trust, frequency of past behavior, and moral norm). When setting the impact of satisfaction, green trust, and frequency of past behavior to zero, the standardized parameter estimate of the moral norm - intention relationship was $.70(p<.01)$. When the impact of other paths was constrained, the standardized parameter estimate of the satisfaction - intention relationship was $.50(\mathrm{p}<.01)$. Similarly, under constraint models, the green trust - intention relationship $(\beta=.51, \mathrm{p}<.01)$ and the frequency of past behavior - intention link $(\beta=.54, \mathrm{p}<.01)$ were positive and significant. This empirical evidence indicates that the newly added constructs independently contributed to increasing pro -environmental intention and improving the prediction of intention. While this result validated the expansion of the value-belief-norm theory with the integration of satisfaction, green trust, and frequency of past behavior into the theory, moral norm was still the stronger influential factor on pro-environmental intention as compared to the added concepts.

\section{Discussion}

This study utilized the value-belief-norm model as a theoretical base for the explication of museum vacationers' pro-environmental intention formation and expanded it by integrating satisfaction with green product use, green trust, and frequency of past behavior for green product use into one conceptual model. Results of the structural equation modeling indicated that the formation of vacationers' intention was significantly driven by these newly integrated 
variables and the theory's original variables. The parsimonious final model was generated through a series of modeling comparisons. In addition, our conceptual framework established the sequential value-belief-norm process (sequential mediating framework) of engendering vacationers' intention for environmentally responsible museums. The explanatory ability of the final model for anticipating intention was stronger than that of the original value-beliefnorm theory and the proposed model. In sum, study variables in the final model satisfactorily accounted for museum vacationers' intention. With a lack of environment related study in a museum context, the present research provided valuable insights into clearly understanding vacationers' pro-environmental decision-making process for environmentally responsible museum products.

Joining the influence of other research variables within the original value-beliefnorm framework, integrated variables (satisfaction with green product use, green trust, and frequency of past behavior for green product use) acted as critical constructs in significantly enhancing the prediction power of the theory and directly increasing vacationers' proenvironmental intention. In line with Fornara et al. (2016), Harland et al. (2007), and Choi et al.'s (2015) assertion, museum vacationers' intention was insufficiently accounted for by the pure form of the value-belief-norm theory. Our further expansion of the formal value-beliefnorm structure with such key environment constructs led to a significant increase of its prediction ability. Our empirical result is theoretically meaningful since it confirmed the theorization that vacationers holding high biospheric and egoistic values, having environmental worldview, and perceiving high problem awareness and ability to reduce threats are likely to have a strong moral norm for pro-environmental decision/behavior; this moral obligation together with satisfaction with eco-friendly product use, frequency of such product use, and green trust build vacationers' eco-friendly decision. This theorization 
developed in this research offers vital insights into the apparent understanding of museum vacationers' environmentally responsible decision-making process and action.

Practitioners should actively enhance visitors' perception of the likely benefits (e.g., safety, health, energy saving) of green product use in everyday life through such diverse ways as advertising campaigns informing the personal advantages of green living and green consumption. These efforts will help visitors be more satisfied with eco-friendly product use, more feel confidence in green product and its attributes performances, and increase the frequency of green product use. Overall, based on our empirical results, such endeavors will be eventually helpful for the increase of museum visitors' pro-environmental decisions.

In contrast to our assumption, the relationship between altruistic value and new environmental paradigm was identified as insignificant. In addition, this variable did not affect other study variables indirectly through new environmental paradigm. However, the other values (biospheric and egoistic values) were found to be significantly associated with new environmental paradigm and to have an important role in generating awareness of consequences. These findings implied that while people's self-transcendence biospheric value and self-enhancing value (i.e., egoistic value) as an important guiding principle in their life is likely to increase new environmental paradigm and awareness of environmental problems, individuals' altruistic value is not significantly related to the enhancement of such an ecological worldview or awareness. Our result suggested that it is not essential to consider the role of value with altruistic nature in explaining museum vacationers' eco-friendly intention/behavior.

De Groot and Steg (2007) developed a value construct that makes a distinction between altruistic and bioshperic value orientations. The separate biospheric value orientation emerged when the ecological problems were more visible (De Groot \& Steg, 2007). Based on Stern's (2000) original proposition of the value-belief-norm theory of environmentalism and 
De Groot and Steg's (2007) indication, the three distinct dimensions of value were utilized in the present study. In line with these researchers' assertion, the assessment of our measurement model demonstrated the difference on biospheric and altruistic value dimensions and validated the measurement instructs for each value dimension. That is, biospheric and altruistic values played an independent role in our research context. Given these evidences, it would be useful to individualize biospheric and altruistic values when explaining customers' environmental worldview and environmentally responsible decision formation.

The results of this study empirically identified the prominent role of moral obligation in building vacationers' behavioral intention for environmentally responsible museum products. This finding was in line with findings in previous studies (Klöckner, 2013; Han, 2015; Zhang et al., 2013). While the contrition of each of the constructs within the valuebelief-norm framework will depend on the behavior being considered, researchers should recognize the significance of the pro-environmental personal norm, use this important variable as a key for explicating other pro-environmental behaviors in hospitality and tourism (e.g., lodging, restaurant, convention, casino, and airline), and employ the personal norm as a core concept for theory building in environmental behaviors.

According to the original value-belief-norm framework, moral norm and its predictors (i.e., ascription of responsibility, awareness of consequences, and new environmental paradigm) mediate the influence of its antecedent(s) on its outcome variable (Stern, 2000; Stern et al., 1999). Such mediating framework was in line with our result, which demonstrated the significant mediating role of these variables in the proposed model. In particular, moral norm was a significant mediator bridging the ascribed responsibility intention linkage; ascribed responsibility mediated the problem awareness - moral norm link; and, awareness of consequences mediated the new environmental paradigm - ascribed 
responsibility linkage. Researchers should understand the mediating nature of these constructs when utilizing them for theory/model development rooted in pro-social/selfinterest motives.

Interestingly, among three value constructs, the impact of biospheric value was the only one mediated by the new environmental paradigm. This result was coherent with some researchers' assertion that biospheric value is particularly important in explicating hospitality/tourism customers' pro-environmental intention formation (e.g., Choi et al., 2015; Han, 2015). In their studies, awareness of consequences significantly mediated the influence of biospheric value on ascribed responsibility. Theoretically, researchers in hospitality and tourism must understand awareness of consequences as an important mediator particularly bridging the biospheric value - ascribed responsibility relationship. From a practical perspective, for the best use of biospheric value in generating museum visitors' proenvironmental intention, dealing with the awareness of consequences in an effective manner is essential.

The present study includes several limitations. First, as indicated earlier, the data collection was done at one metropolitan city in Korea. In order to enhance an external validity, a broader sampling range in many geographical areas needs to be included in future studies. Second, demographics and motivations, which are not considered in this study, can be important factors. Museum vacationers' environmentally responsible decisions and behaviors would be better explicated by considering the role of these factors. In future research, our proposed model can be further deepened and broadened by taking these factors into account. Lastly, the number of responses from the eight museums where the data were collected was somewhat uneven ( 23 responses from one palace museum, 59 responses from one war museum, 100 responses from one art museum, etc.). Thus, conducting a chi-square test for eight different measurement models was not feasible. Future research should consider 
making the number of responses from each museum to be more evenly when colleting the data.

\section{References}

Ajzen, I. (1991). The theory of planned behavior. Organizational Behavior and Human Decision Processes, 50(2), 179-211.

Ajzen, I. (2002). Residual effect of past on later behavior: Habituation and reasoned action perspectives. Personality and Social Psychology Review, 6(2), 107-122.

Asgharian, R., Salehi, M., Saleki, Z.S., Hojabri, R., \& Nikkheslat, M. (2012). Green product quality, green customer satisfaction, and green customer loyalty. International Journal of Research in Management and Technology, 2(5), 2249-9563.

Bamberg, S., \& Möser, G. (2007). Twenty years after Hines, Hungerford, and Tomera: A new meta-analysis of psycho-social determinants of pro-environmental behavior. Journal of Environmental Psychology, 27, 14-25.

Bamberg, S., Hunecke, M., \& Blobaum, A. (2007). Social context, personal norms and the use of public transportation: Two field studies. Journal of Environmental Psychology, 27, 190-203.

Brophy, S.S., \& Wylie, E. (2006, September/October). It's easy being green: Museums and the green movement. Museum News, 38 -45.

Brophy, S.S., \& Wylie, E. (2008). The green museum: A primer on environmental practice. Lanham, MD: AltaMira Press.

Byers, R. (2008). Green museums and green exhibits: Communicating sustainability through content and design. Unpublished master's thesis, University of Oregon.

Chan, L., \& Bishop, B. (2013). A moral basis for recycling: Extending the theory of planned behavior. Journal of Environmental Psychology, 36, 96-102.

Chang, N., \& Fong, C. (2010). Green product quality, green corporate image, green customer satisfaction, and green customer loyalty. African Journal of Business Management, 4(13), 2836-2844.

Chen, C., Chen, S.H., \& Lee, H.T. (2011). The destination competitiveness of Kinmen's tourism industry: Exploring the interrelationships between tourist perceptions, service performance, customer satisfaction and sustainable tourism. Journal of Sustainable Tourism, 19(2), 247-264.

Chen, Y. (2010). The drivers of green brand equity: Green brand image, green satisfaction, and green trust. Journal of Business Ethics, 93(2), 307-319.

Chen, Y. (2013). Towards green loyalty: Driving from green perceived value, green satisfaction, and green trust. Sustainable Development, 21(5), 294-308. 
Chen, Y., \& Chang, C. (2013). Green wash and green trust: The mediation effects of green consumer confusion and green perceived risk. Journal of Business Ethics, 114(3), 489-500.

Choi, H., Jang, J., \& Kandampully, J. (2015). Application of the extended VBN theory to understand consumers' decisions about green hotels. International Journal of Hospitality Management, 51, 87-95.

Cordano, M., Welcomer, S., Scherer, R., \& Parada, V. (2011). Understanding cultural differences in the antecedents of pro-environmental behavior: A comparative analysis of business student in the United States and Chile. Journal of Environmental Education, 41, 224-238.

De Groot, J.I.M., \& Steg, L. (2007). General beliefs and the theory of planned behavior: The role of environmental concerns in the TPB. Journal of Applied Social Psychology, 37, 1817-1836.

De Groot, J.I.M., \& Steg, L. (2009). Morality and prosocial behavior: The role of awareness, responsibility, and norms in the norm activation model. Journal of Social Psychology, 149(9), 425-449.

De Groot, J.I.M., Steg, L., \& Dicke, M. (2007). Morality and reducing car use: Testing the norm activation model of prosocial behavior. In F. Columbus (Ed.), Transportation Research Trends. NOVA Publishers.

Dunlap, R.E., \& Van Liere, K.D. (1978). The "new environmental paradigm": A proposed measuring instrument and preliminary results. Journal of Environmental Education, 9, 10-19.

Dunlap, R.E., Van Liere, K.D., Mertig, A.G., \& Jones, R.E. (2000). Measuring endorsement of the new ecological paradigm: A revised NEP scale. Journal of Social Issues, 56, $425-442$.

Fornara, F., Pattitoni, P., Mura, M., \& Strazzera, E. (2016). Predicting intention to improve household energy efficiency: The role of value-belief-norm theory, normative and informational influence, and specific attitude. Journal of Environmental Psychology, $45,1-10$.

Fornell, C., \& Larcker, D.F. (1981). Evaluating structural equation models with unobservable variables and measurement error. Journal of Marketing Research, 18, 39-50.

Hair, J.F., Black, W.C., Babin, B.J., \& Anderson, R.E. (2010). Multivariate data analysis ( $7^{\text {th }}$ ed.). Upper Saddle River, NJ: Prentice-Hall.

Han, H. (2014). The norm activation model and theory-broadening: Individuals' decisionmaking on environmentally-responsible convention attendance. Journal of Environmental Psychology, 40, 462-471.

Han, H. (2015). Travelers' pro-environmental behavior in a green lodging context: Converging value-belief-norm theory and the theory of planned behavior. Tourism Management, 47, 164-177. 
Han, H., \& Hyun, S. (2017). Fostering customers' pro-environmental behavior at a museum. Journal of Sustainable Tourism, DOI: 10.1080/09669582.2016.1259318.

Han, H., \& Ryu, K. (2012). The theory of repurchase decision-making (TRD): Identifying the critical factors in the post-purchase decision-making process. International Journal of Hospitality Management, 31(3), 786-797.

Han, H., \& Yoon, H. (2015). Customer retention in the eco-friendly hotel sector: Examining the diverse processes of post-purchase decision-making. Journal of Sustainable Tourism, 23(7), 1095-1113.

Han, H., Hsu, L., \& Sheu, C. (2010). Application of the theory of planned behavior to green hotel choice: Testing the effect of environmental friendly activities. Tourism Management, 31, 325-334.

Han, H., Hwang, J., \& Lee, M. (2016). The value-belief-emotion-norm model: Investigating customers' eco-friendly behavior. Journal of Travel and Tourism Marketing, DOI: 10.1080/10548408.2016.1208790.

Hwang, J., \& Hyun, S. (2017). First -class airline travelers' tendency to seek uniqueness: How does it influence their purchase of expensive tickets? Journal of Travel \& Tourism Marketing, 34(7), 935-947.

Harland, P., Staats, H., \& Wilke, H.A.M. (2007). Situational and personality factors as direct or personal norm mediated predictors of pro-environmental behavior: Questions derived fro norm-activation theory. Basic \& Applied Social Psychology, 29(4), 323-334.

Hopper, J.R., \& Nielsen, J.M. (1991). Recycling as altruistic behavior: Normative and behavioral strategies to expand participation in a community recycling program. Environment and Behavior, 23, 195-220.

Jakovcevic, A., \& Steg, L. (2013). Sustainable transportation in Argentina: Values, beliefs, norms and car use reduction. Transportation Research-F, 20, 70-79.

Jamal, A. (2004). Retail banking and customer behavior: A study of self concept, satisfaction and technology usage. International Review of Retail, Distribution and Consumer Research, 14(3), 357-379.

Jani, D., \& Han, H. (2014). Testing the moderation effect of hotel ambience on the relationships among social comparison, affect, satisfaction, and behavioral intentions. Journal of Travel and Tourism Marketing, 31, 731-746.

Kang, S., \& Hur, W. (2012). Investigating the antecedents of green brand equity: A sustainable development perspective. Corporate Social Responsibility and Environmental Management, 19, 306-316.

Kim, Y., \& Han, H. (2010). Intention to pay conventional-hotel prices at a green hotel - A modification of the theory of planned behavior. Journal of Sustainable Tourism, 18(8). 997-1014.

Klöckner, C.A. (2013). A comprehensive model of the psychology of environmental behavior - A meta-analysis. Global Environmental Change, 23, 1028-

1038. 27 
Klöckner, C.A., \& Matthies, E., (2004). How habits interfere with norm directed behavior A normative decision-making model for travel mode choice. Journal of Environmental Psychology, 24, 319-327.

López-Mosquera, N., \& Sánchez, M. (2012). Theory of planned behavior and the valuebelief-norm theory explaining willingness to pay for a suburban park. Journal of Environmental Management, 113, 251-262.

Martínez, P., \& Rodríguez del Bosque, L. (2013). CSR and consumer loyalty: The roles of trust, consumer identification with the company and satisfaction. International Journal of Hospitality Management, 35, 89-99.

Mayer, R.C., Davis, J.H., \& Schoorman, F.D. (1995). An integrative model of organizational trust. Academy of Management Review, 20(3), 709-734.

Milfont, T.L., Sibley, C.G., \& Duckitt, J. (2010). Testing the moderating role of the components of norm activation on the relationship between values and environmental behavior. Journal of Cross-Cultural Psychology, 41, 124-131.

Moorman, C., Deshpande, R., \& Zaltman, G. (1993). Factors affecting trust in market research relationship. Journal of Marketing, 57, 81-101.

Morgan, R.M., \& Hunt, S.D. (1994). The commitment-trust theory of relationship marketing. Journal of Marketing, 58, 20-38.

Okello, M.M., \& Yerian, S. (2009). Tourist satisfaction in relation to attractions and implications for conservation in the protected areas of the Northern Circuit, Tanzania. Journal of Sustainable Tourism, 17(5), 605 -625.

Oliver, R.L. (1997). Satisfaction: A behavioral perspective on the consumer. New York, NY: McGraw-Hill.

Oliver, R.L. (2006). Customer satisfaction research: The handbook of marketing research. California: Sage.

Onwezen, M.C., Antonides, G., \& Bartels, J. (2013). The norm activation model: An exploration of the functions of anticipated pride and guilt in pro-environmental behavior. Journal of Economic Psychology, 39, 141-153.

Oreg, S., \& Katz-Gerro, T. (2006). Predicting proenvironmental behavior cross-nationality: Value, the theory of planned behavior, and value-belief-norm theory. Environment and Behavior, 38(4), 462-483.

Parasuraman, A., Zeithaml, V.A., \& Berry, L.L. (1985). A conceptual model of service quality and its implications for future research. Journal of Marketing, 49(4), 49(4), 41-50.

Perugini, M., \& Bagozzi, R.P. (2001). The role of desires and anticipated emotions in goaldirected behaviors: Broadening and deepening the theory of planned behavior. British Journal of Social Psychology 40, 79-98.

Schwartz, S.H. (1977). Normative influence on altruism. In L. Berkowitz (Ed.), Advances in Experimental Social Psychology 10 (pp. 221-279). New York, NY: Academic Press. 
Schwartz, S.H. (1992). Universals in the content and structure of values: Theoretical advances and empirical tests in 20 countries. Advances in Experimental Social Psychology, 25, 1-65.

Sommer, L. (2011). The theory of planned behaviour and the impact of past behavior. International Business and Economics Research Journal, 10(1), 91-110.

Song, H., Lee, C., Kang, S., \& Boo, S. (2012). The effect of environmentally friendly perceptions on festival visitors' decision-making process using an extended model of goal-directed behavior. Tourism Management, 33, 1417-1428.

Sparks, B.A., \& Browning, V. (2011). The impact of online reviews on hotel booking intentions and perception of trust. Tourism Management, 32(6), 1310-1323.

Steg, L., Dreijerink, L., \& Abrahamse, W. (2005). Factors influencing the acceptability of energy policies: A test of VBN theory. Journal of Environmental Psychology, 25(4), 415-425.

Stern, P.C. (2000). Toward a coherent theory of environmentally significant behavior. Journal of Social Issues, 56 (3), 407-424.

Stern, P.C., Dietz, T., \& Kalof, L. (1993). Value orientations, gender, and environmental concern. Environment and Behavior, 25(5), 322-348.

Stern, P.C., Dietz, T., Abel, T., Guagnano, G.A., \& Kalof, L. (1999). A value-belief-norm theory of support for social movements: The case of environmentalism. Research in Human Ecology, 6(2), 81-97.

Teraji, S. (2009). A model of corporate social performance: Social satisfaction and moral conduct. The Journal of Socio-Economics, 38, 926-934.

Van der Werff, E., \& Steg, L. (2016). The psychology of participation and interest in smart energy systems: Comparing the value-belief-norm theory and the value-identifypersonal norm model. Energy Research \& Social Science, 22, 107-114.

Van Riper, C.J., \& Kyle, G.T. (2014). Understanding the internal processes of behavioral engagement in a national park: A latent variable path analysis of the value-beliefnorm theory. Journal of Environmental Psychology, 38, 288-297.

Vining, J., \& Ebreo, A. (1992). Predicting recycling behavior from global and specific environmental attitudes and changes in recycling opportunities. Journal of Applied Social Psychology, 22, 1580-1607.

Worts, D. (2004). Museums in search of a sustainable future. Alberta Museums Reviews, 40-57.

Worts, D. (2006). Fostering a culture of sustainability. Museums and Social Issues, 1(2), 151-172.

Worts, D. (2011). Sustainable museums: Strategies for the $21^{\text {st }}$ century. Museum Management and Curatorship, 24(4), 409-412. 
Wylie, E., \& Brophy, S.S. (2008, January/February). The greener good: The enviro-active museum. Museum, 40-47.

Zhang, Y., Wang, Z., \& Zhou, G. (2013). Antecedents of employee electricity saving behavior in organizations: An empirical study based on norm activation model. Energy Policy, 62, 1120-1127. 
Table 1. Measurement quality assessment and correlations

\begin{tabular}{|c|c|c|c|c|c|c|c|c|c|c|c|c|c|}
\hline & BV & AV & EV & NEP & $\mathrm{AC}$ & $\mathrm{AR}$ & $\mathrm{MN}$ & SGPU & GT & FPBGPU & PI & CR & AVE \\
\hline$\overline{B V}$ & - & & & & & & & & & & & .88 & .65 \\
\hline AV & $\begin{array}{c}.58^{\mathrm{a}} \\
(.34)^{\mathrm{b}}\end{array}$ & - & & & & & & & & & & .88 & .64 \\
\hline EV & $\begin{array}{c}.09 \\
(.01)\end{array}$ & $\begin{array}{c}.22 \\
(.05)\end{array}$ & - & & & & & & & & & .88 & .59 \\
\hline NEP & $\begin{array}{c}.47 \\
(.22)\end{array}$ & $\begin{array}{c}.39 \\
(.15)\end{array}$ & $\begin{array}{c}.19 \\
(.04)\end{array}$ & - & & & & & & & & .82 & .48 \\
\hline $\mathrm{AC}$ & $\begin{array}{l}.15 \\
(.02)\end{array}$ & $\begin{array}{c}.11 \\
(.01)\end{array}$ & $\begin{array}{c}.25 \\
(.06)\end{array}$ & $\begin{array}{c}.30 \\
(.09)\end{array}$ & - & & & & & & & .89 & .66 \\
\hline AR & $\begin{array}{c}.17 \\
(.03)\end{array}$ & $\begin{array}{c}.12 \\
(.01)\end{array}$ & $\begin{array}{c}.12 \\
(.01)\end{array}$ & $\begin{array}{c}.25 \\
(.06)\end{array}$ & $\begin{array}{c}.57 \\
(.32)\end{array}$ & - & & & & & & .91 & .78 \\
\hline $\mathrm{MN}$ & $\begin{array}{c}.32 \\
(.10)\end{array}$ & $\begin{array}{c}.23 \\
(.05)\end{array}$ & $\begin{array}{c}.06 \\
(.01)\end{array}$ & $\begin{array}{c}.23 \\
(.05)\end{array}$ & $\begin{array}{c}.40 \\
(.16)\end{array}$ & $\begin{array}{c}.43 \\
(.18)\end{array}$ & - & & & & & .88 & .66 \\
\hline SGPU & $\begin{array}{c}.43 \\
(.18)\end{array}$ & $\begin{array}{c}.38 \\
(.14)\end{array}$ & $\begin{array}{l}.13 \\
(.02)\end{array}$ & $\begin{array}{c}.35 \\
(.12)\end{array}$ & $\begin{array}{c}.18 \\
(.03)\end{array}$ & $\begin{array}{c}.28 \\
(.08)\end{array}$ & $\begin{array}{c}.37 \\
(.14)\end{array}$ & - & & & & .94 & .85 \\
\hline GT & $\begin{array}{c}.41 \\
(.17)\end{array}$ & $\begin{array}{c}.37 \\
(.14)\end{array}$ & $\begin{array}{c}.17 \\
(.03)\end{array}$ & $\begin{array}{c}.38 \\
(.14)\end{array}$ & $\begin{array}{c}.18 \\
(.03)\end{array}$ & $\begin{array}{l}.16 \\
(.03)\end{array}$ & $\begin{array}{c}.31 \\
(.10)\end{array}$ & $\begin{array}{c}.48 \\
(.23)\end{array}$ & - & & & .75 & .51 \\
\hline FPBGPU & $\begin{array}{c}.28 \\
(.08)\end{array}$ & $\begin{array}{c}.21 \\
(.04)\end{array}$ & $\begin{array}{c}.18 \\
(.03)\end{array}$ & $\begin{array}{c}.30 \\
(.09)\end{array}$ & $\begin{array}{c}.22 \\
(.05)\end{array}$ & $\begin{array}{c}.32 \\
(.10)\end{array}$ & $\begin{array}{c}.42 \\
(.18)\end{array}$ & $\begin{array}{c}.38 \\
(.14)\end{array}$ & $\begin{array}{c}.37 \\
(.14)\end{array}$ & - & & .89 & .80 \\
\hline PI & $\begin{array}{c}.41 \\
(.17) \\
\end{array}$ & $\begin{array}{c}.31 \\
(.10) \\
\end{array}$ & $\begin{array}{c}.07 \\
(.01) \\
\end{array}$ & $\begin{array}{c}.27 \\
(.07) \\
\end{array}$ & $\begin{array}{c}.22 \\
(.05) \\
\end{array}$ & $\begin{array}{c}.31 \\
(.10) \\
\end{array}$ & $\begin{array}{r}.56 \\
(.31) \\
\end{array}$ & $\begin{array}{r}.45 \\
(.20) \\
\end{array}$ & $\begin{array}{r}.39 \\
(.15) \\
\end{array}$ & $\begin{array}{c}.45 \\
(.20) \\
\end{array}$ & - & .89 & .74 \\
\hline $\begin{array}{l}\text { Mean } \\
\text { SD }\end{array}$ & $\begin{array}{c}5.42 \\
.97\end{array}$ & $\begin{array}{l}5.45 \\
1.00\end{array}$ & $\begin{array}{l}4.59 \\
1.10\end{array}$ & $\begin{array}{c}5.18 \\
.96\end{array}$ & $\begin{array}{l}4.14 \\
1.08\end{array}$ & $\begin{array}{l}4.13 \\
1.16\end{array}$ & $\begin{array}{l}4.28 \\
1.10\end{array}$ & $\begin{array}{l}5.44 \\
1.07\end{array}$ & $\begin{array}{c}5.13 \\
.93\end{array}$ & $\begin{array}{l}4.38 \\
1.13\end{array}$ & $\begin{array}{l}4.81 \\
1.08\end{array}$ & & \\
\hline
\end{tabular}

Note1. $\mathrm{BV}=$ biospheric value, $\mathrm{AV}=$ altruistic value, $\mathrm{EV}=$ egoistic value, $\mathrm{NEP}=$ new environmental paradigm, $\mathrm{AC}=$ awareness of consequences, $\mathrm{AR}=$

ascription of responsibility, $\mathrm{MN}=$ moral norm, $\mathrm{SGPU}=$ satisfaction with green product use, $\mathrm{GT}=$ green trust, $\mathrm{FPBGPU}=$ frequency of past behavior for green

product use, $\mathrm{PI}=$ pro-environmental intention, $\mathrm{CR}=$ composite reliability, $\mathrm{AVE}=$ average variance extracted

Note2. Goodness-of-fit statistics: $\chi^{2}=1515.28, d f=683, \chi^{2} / d f=2.22, p<.001$, RMSEA $=.053$, CFI $=.92$, IFI $=.93$, TLI $=.92$

${ }^{\text {a }}$ Correlations between study constructs

${ }^{b}$ Squared correlations between research variables 
Table 2. Structural-model comparisons

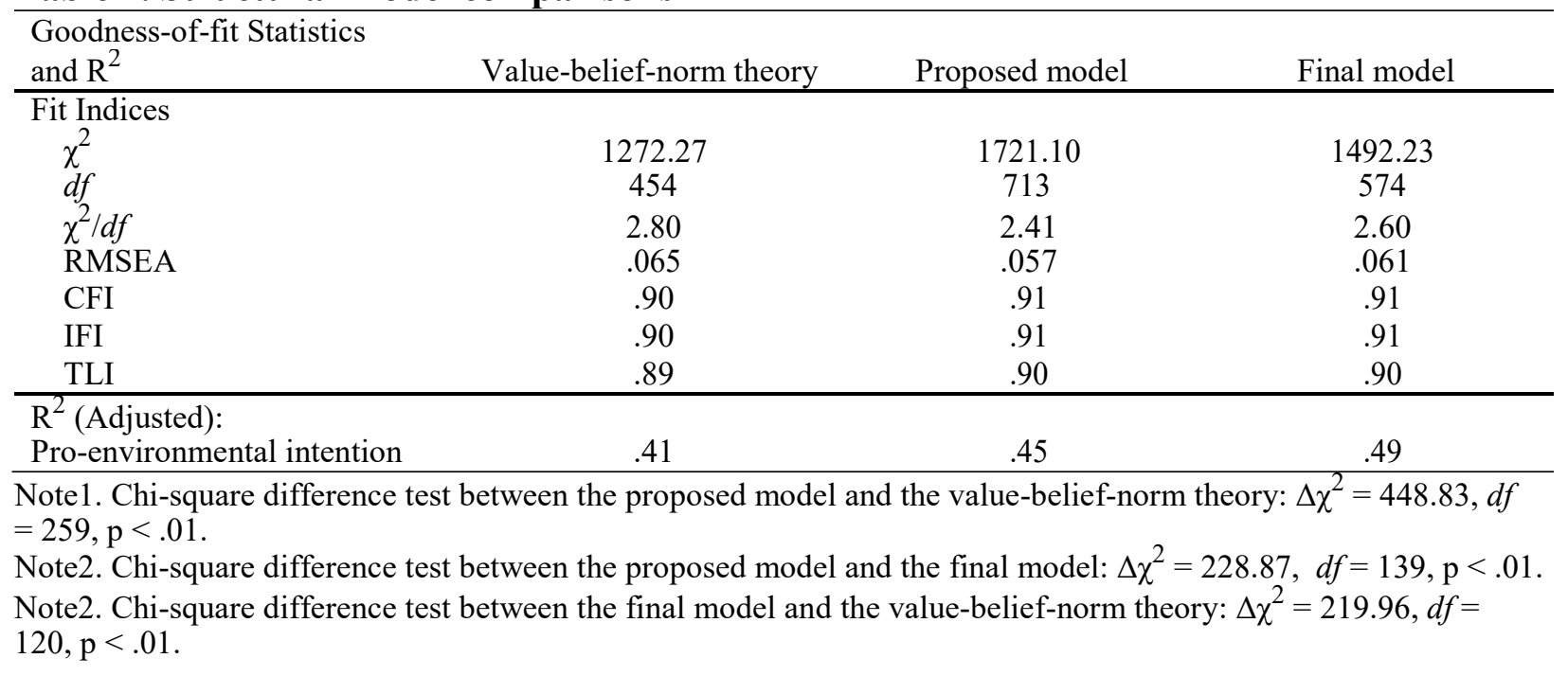


Table 3. Structural model assessment

\begin{tabular}{|c|c|c|c|}
\hline Hypothesis & Path & $\begin{array}{c}\text { Coefficients } \\
\text { (original VBN model, } \\
\text { proposed model, final } \\
\text { model) }\end{array}$ & $\begin{array}{c}\mathrm{t} \text {-values } \\
\text { (original VBN model, } \\
\text { proposed model, final } \\
\text { model) }\end{array}$ \\
\hline Hypothesis 1 & BV NEP & $.47, .49, .56$ & $6.16^{* *}, 6.38^{* *}, 9.88^{* *}$ \\
\hline Hypothesis 2 & AV NEP & $.13, .11,-$ & $1.68,1.53,-$ \\
\hline Hypothesis 3 & EV NEP & $.14, .14, .17$ & $2.66^{* *}, 2.77^{* *}, 3.27^{* *}$ \\
\hline Hypothesis 4 & NEP AC & $.31, .31, .31$ & $5.46^{* *}, 5.48^{* *}, 5.52^{* *}$ \\
\hline Hypothesis 5 & $\mathrm{AC}$ AR & $.60, .60, .60$ & $11.49^{* *}, 11.48^{* *}, 11.42^{* *}$ \\
\hline Hypothesis 6 & AR MN & $.49, .49, .34$ & $9.11^{* *}, 8.62 * *, 6.30^{* *}$ \\
\hline Hypothesis 7 & MN PI & $.64, .49, .48$ & $11.79 * *, 8.21 * *, 7.61^{* *}$ \\
\hline Hypothesis 8 & SGPU PI & $-, .18, .13$ & $-, 2.92 * *, 2.25 *$ \\
\hline Hypothesis 9 & GT PI & $-, .17, .13$ & $-, 2.56^{*}, 2.20^{*}$ \\
\hline Hypothesis 10 & FPBGPU PI & $-, .19, .17$ & $-, 3.42 * *, 2.92^{* *}$ \\
\hline & SGPU MN &,,-- .23 &,,$-- 3.70^{* *}$ \\
\hline & SGPU GT &,,-- .57 &,,$-- 8.78 * *$ \\
\hline & FPBGPU MN &,,-- .31 &,,$-- 5.21 * *$ \\
\hline & GT MN & $-, .12,-$ & $-, 1.65,-$ \\
\hline $\begin{array}{l}\text { Variance explained } \\
\text { (original VBN model, }\end{array}$ & $\begin{array}{l}\text { Total effect on PI (original } \\
\text { VBN model, proposed model, }\end{array}$ & \multicolumn{2}{|c|}{$\begin{array}{l}\text { Indirect effect (original VBN model, proposed model, } \\
\text { final model): }\end{array}$} \\
\hline proposed model, final & final model): & \multicolumn{2}{|c|}{$\beta \mathrm{AR} \rightarrow \mathrm{MN} \rightarrow \mathrm{PI}=.31^{* *}, .24^{* *}, .16^{*}$} \\
\hline model): & $\beta \mathrm{MN}=.64 * *, .49 * *, 48^{* *}$ & \multicolumn{2}{|c|}{$\beta \mathrm{AC} \rightarrow \mathrm{AR} \rightarrow \mathrm{MN}=.29^{* *}, .29^{* *} .20^{* *}$} \\
\hline $\mathrm{R}\left(\mathrm{PI}^{2}\right)=.41, .45, .49$ & $\beta \mathrm{SGPU}=-, .18^{* *}, 32^{* *}$ & \multicolumn{2}{|c|}{$\beta \mathrm{NEP} \rightarrow \mathrm{AC} \rightarrow \mathrm{AR}=.19^{* *}, .19^{* *}, .19^{* *}$} \\
\hline $\mathrm{R}\left(\mathrm{MN}^{2}\right)=.24,24, .34$ & $\beta \mathrm{GT}=-, .17^{*}, 13^{*}$ & \multicolumn{2}{|c|}{$\beta \mathrm{BV} \rightarrow \mathrm{NEP} \rightarrow \mathrm{AC}=.14^{* *}, .15^{* *}, .17^{* *}$} \\
\hline $\mathrm{R}\left(\mathrm{AR}^{2}\right)=.36,36,36$ & $\beta$ FPBGPU $=-, .19^{* *}, 32^{* *}$ & \multicolumn{2}{|c|}{$\beta \mathrm{AV} \rightarrow \mathrm{NEP} \rightarrow \mathrm{AC}=.04, .04,-$} \\
\hline $\mathrm{R}\left(\mathrm{A}^{2} \mathrm{C}\right)=.10, .10, .10$ & $\beta \mathrm{AR}=.31^{* *}, .24^{* *}, .16^{*}$ & \multicolumn{2}{|c|}{$\beta_{\beta} \mathrm{EV} \rightarrow \mathrm{NEP} \rightarrow \mathrm{AC}=.04, .05, .05$} \\
\hline $\mathrm{R}^{2}(\mathrm{NEP})=.35,36,35$ & $\beta \mathrm{AC}=.19^{* *}, .15^{* *}, .10^{*}$ & \multirow{2}{*}{\multicolumn{2}{|c|}{ 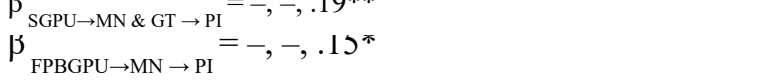 }} \\
\hline \multirow[t]{3}{*}{$\mathrm{R}^{2}(\mathrm{GT})=-,-, .32$} & $\beta \mathrm{NEP}=.06, .05, .03$ & & \\
\hline & $\begin{array}{l}\beta \mathrm{BV}=.03, .02, .02 \\
\beta \mathrm{AV}=01.01 .-\end{array}$ & & \\
\hline & $\beta \mathrm{EV}=.01, .01, .01$ & \multicolumn{2}{|l|}{$* p<.05, * * p<.01$} \\
\hline
\end{tabular}

Note1. $\mathrm{BV}=$ biospheric value, $\mathrm{AV}=$ altruistic value, $\mathrm{EV}=$ egoistic value, $\mathrm{NEP}=$ new environmental paradigm, $\mathrm{AC}$

= awareness of consequences, $\mathrm{AR}=$ ascription of responsibility, $\mathrm{MN}=$ moral norm, $\mathrm{SGPU}=$ satisfaction with green

product use, GT = green trust, FPBGPU = frequency of past behavior for green product use, $\mathrm{PI}=$ pro-environmental

intention

Note2. Goodness-of-fit statistics for the original VBN model: $\chi^{2}=1272.72, d f=454, \chi^{2} / d f=2.80, p<.001$, RMSEA

$=.065, \mathrm{CFI}=.90, \mathrm{IFI}=.90, \mathrm{TLI}=.89$

Note3. Goodness-of-fit statistics for the proposed model: $\chi^{2}=1721.10, d f=713, \chi^{2} / d f=2.41, p<.001$, RMSEA $=$ $.057, \mathrm{CFI}=.91, \mathrm{IFI}=.91, \mathrm{TLI}=.90$

Note4. Goodness-of-fit statistics for the final model: $\chi^{2}=1492.23, d f=574, \chi^{2} / d f=2.60, p<.001$, RMSEA $=.061$, $\mathrm{CFI}=.91, \mathrm{IFI}=.91, \mathrm{TLI}=.90$ 
Figure 1. The conceptual model

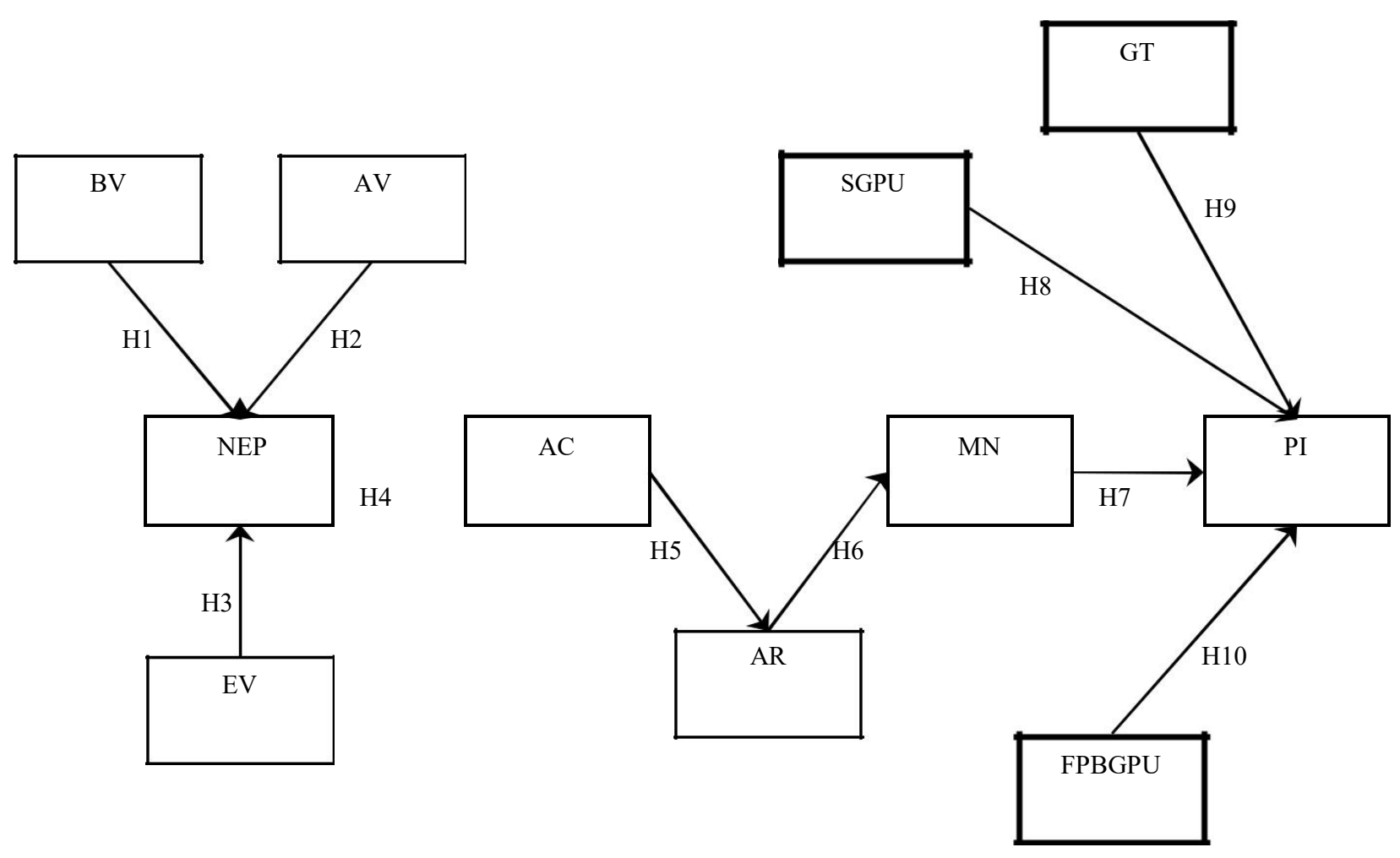

Note1. $\mathrm{BV}=$ biospheric value, $\mathrm{AV}=$ altruistic value, $\mathrm{EV}=$ egoistic value, $\mathrm{NEP}=$ new environmental paradigm, $\mathrm{AC}$ $=$ awareness of consequences, $\mathrm{AR}=$ ascription of responsibility, $\mathrm{MN}=$ moral norm, $\mathrm{SGPU}=$ satisfaction with green product use, GT = green trust, FPBGPU = frequency of past behavior for green product use, $\mathrm{PI}=$ pro-environmental intention

Note2. The bolded variables indicate the newly integrated constructs. 


\section{Figure 2. Structural model results of the original VBN model}

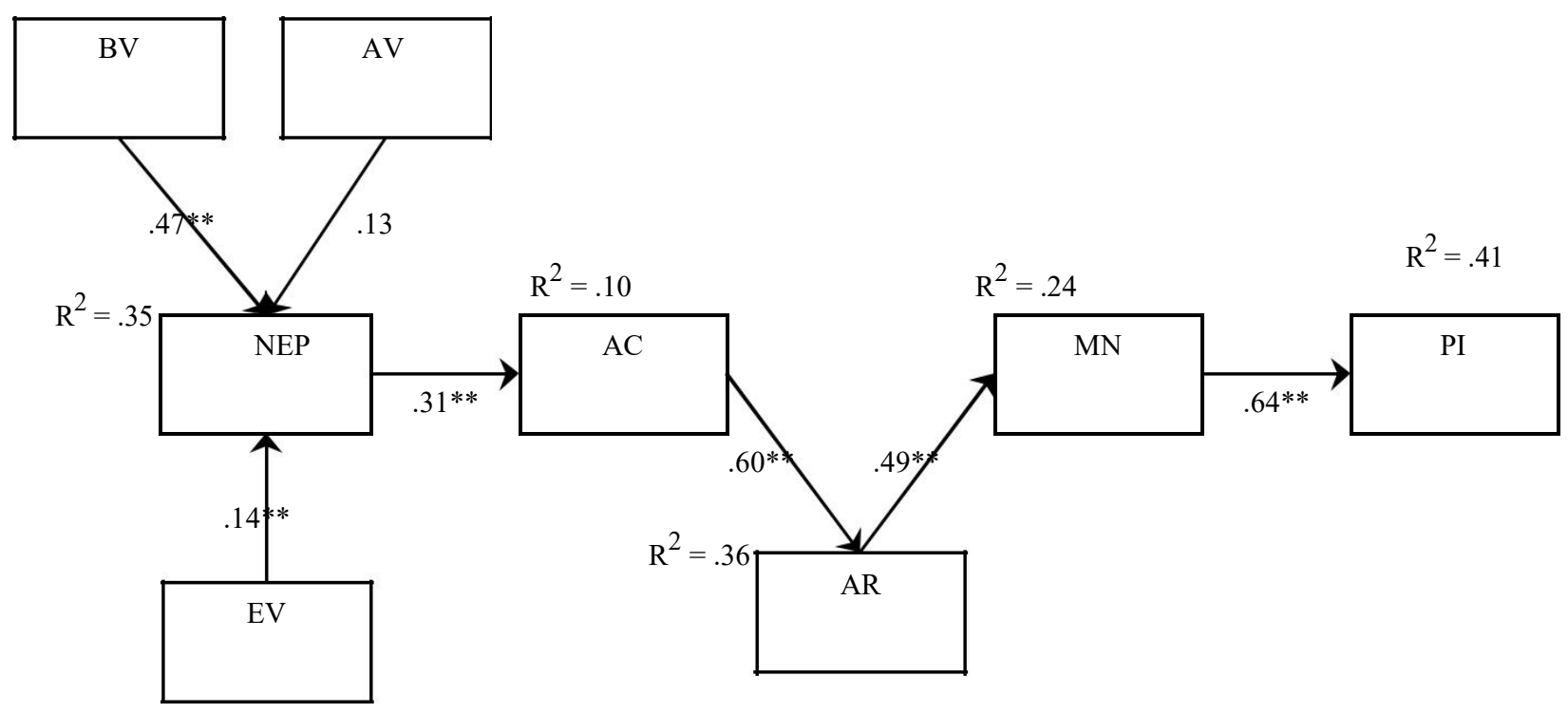

Note1. $\mathrm{BV}=$ biospheric value, $\mathrm{AV}=$ altruistic value, $\mathrm{EV}=$ egoistic value, $\mathrm{NEP}=$ new environmental paradigm, $\mathrm{AC}$ $=$ awareness of consequences, $\mathrm{AR}=$ ascription of responsibility, $\mathrm{MN}=$ moral norm, $\mathrm{SGPU}=$ satisfaction with green product use, GT = green trust, FPBGPU = frequency of past behavior for green product use, $\mathrm{PI}=$ pro-environmental intention

Note2. Goodness-of-fit statistics for the original VBN model: $\chi^{2}=1272.72, d f=454, \chi^{2} / d f=2.80, p<.001$, RMSEA $=.065, \mathrm{CFI}=.90, \mathrm{IFI}=.90, \mathrm{TLI}=.89$ 
Figure 3. Structural model results of the proposed model

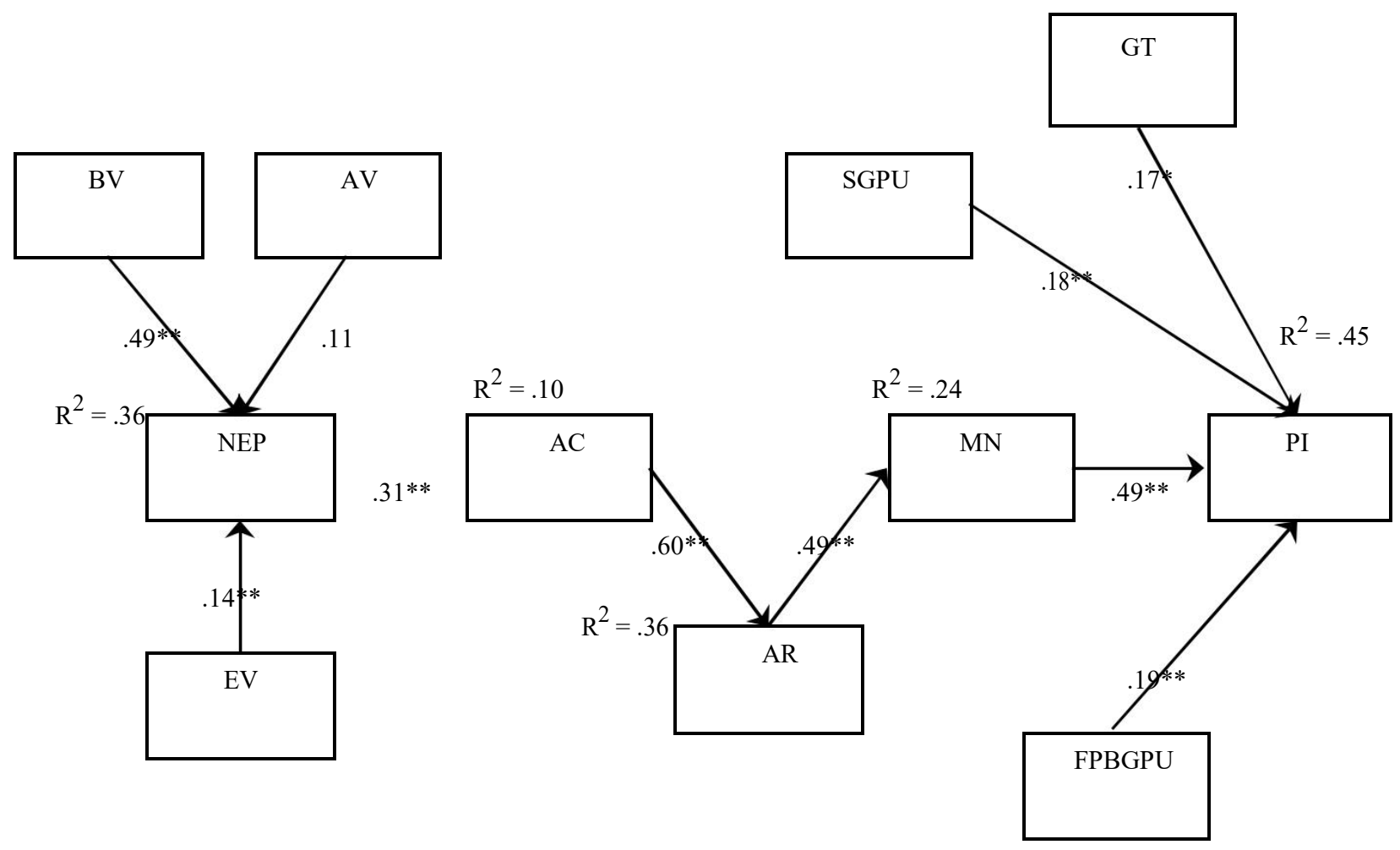

Note1. $\mathrm{BV}=$ biospheric value, $\mathrm{AV}=$ altruistic value, $\mathrm{EV}=$ egoistic value, $\mathrm{NEP}=$ new environmental paradigm, $\mathrm{AC}$ $=$ awareness of consequences, $\mathrm{AR}=$ ascription of responsibility, $\mathrm{MN}=$ moral norm, $\mathrm{SGPU}=$ satisfaction with green product use, GT = green trust, FPBGPU = frequency of past behavior for green product use, $\mathrm{PI}=$ pro-environmental intention

Note2. The bolded variables indicate the newly integrated constructs.

Note3. Goodness-of-fit statistics for the proposed structural model: $\chi^{2}=1721.10, d f=713, \chi^{2} / d f=2.41$, $p<.001, \mathrm{RMSEA}=.057, \mathrm{CFI}=.91, \mathrm{IFI}=.91, \mathrm{TLI}=.90$ 
Figure 4. Structural model results of the final model

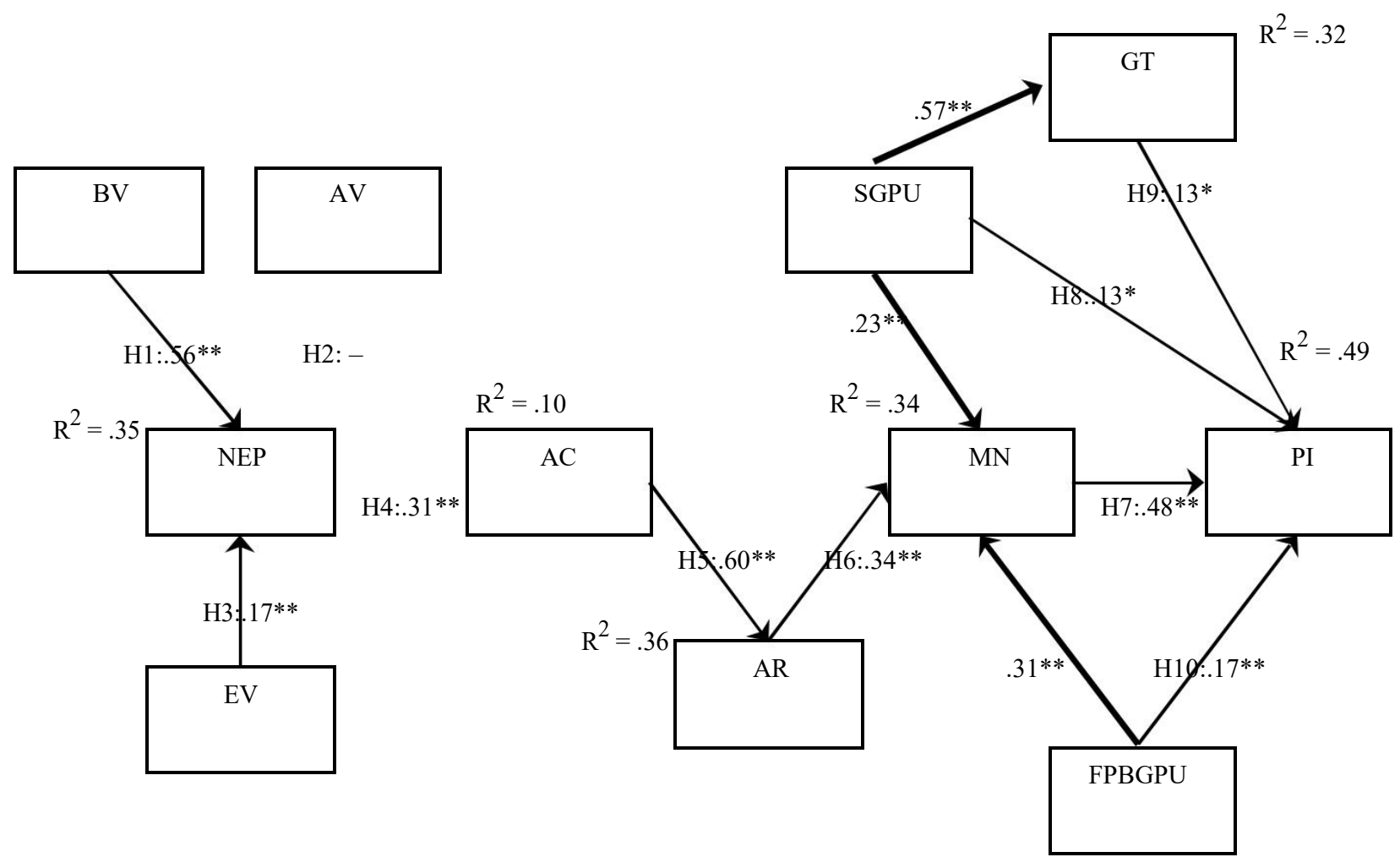

Note1. $\mathrm{BV}=$ biospheric value, $\mathrm{AV}=$ altruistic value, $\mathrm{EV}=$ egoistic value, $\mathrm{NEP}=$ new environmental paradigm, $\mathrm{AC}$ $=$ awareness of consequences, $\mathrm{AR}=$ ascription of responsibility, $\mathrm{MN}=$ moral norm, $\mathrm{SGPU}=$ satisfaction with green product use, GT = green trust, FPBGPU = frequency of past behavior for green product use, $\mathrm{PI}=$ pro-environmental intention

Note2. The bolded variables indicate the newly integrated constructs.

Note3. Bolded lines indicate the paths newly added on the proposed model.

Note4. Goodness-of-fit statistics for the final model: $\chi^{2}=1492.23, d f=574, \chi^{2} / d f=2.60, p<.001$, RMSEA $=$ $.061, \mathrm{CFI}=.91, \mathrm{IFI}=.91, \mathrm{TLI}=.90$ 
Biospheric, altruistic, and egoistic values

(Not very important [1] - Very important [7])

Please indicate to what extent the followings are important as a guiding principle in your life.

Preventing pollution

Respecting the earth $\quad .82$

Unity with nature $\quad .76$

Protecting the environment $\quad .85$

Equality

A world at peace

Social justice $\quad .83$

Helpful $\quad .75$

Social power $\quad .75$

Wealth $\quad .75$

Authority $\quad .85$

$\begin{array}{ll}\text { Influential } & .74\end{array}$

Ambitious $\quad .74$

New environmental paradigm

(Strongly disagree [1] - Strongly agree [7])

The balance of nature is very delicate and easily upset.

$\begin{array}{ll}\text { Humans are severely abusing the environment. } & .79\end{array}$

The earth is like a spaceship with limited room and resources.

The so-called "ecological crisis" facing humankind has been greatly exaggerated.*

The balance of nature is strong enough to cope with the impacts of modern $\quad .74$

industrial nations.*

Awareness of consequences

(Strongly disagree [1] - Strongly agree [7])

The museum industry can possibly have a negative impact on the environment

(e.g., global warming/pollution from heating, ventilation, air conditioning, and lighting).

The museum industry can possibly cause exhaustion of natural resources (e.g., excessive use of water and energy).

The museum industry can possibly cause environmental deteriorations (e.g., greywater and wastes from restaurants, cafés, construction, and other museum facilities).

An environmentally responsible museum practicing energy/water conservation, waste reduction, and diverse green activities helps to minimize environmental degradations.*

Ascription of responsibility

(Strongly disagree [1] - Strongly agree [7])

I believe that every museum traveler is partly responsible for environmental problems possibly caused by museum tourism.

I feel that every museum traveler is jointly responsible for the environmental

deteriorations possibly caused by museum tourism.

Every museum traveler must take some responsibility for the environmental problems possibly caused by museum tourism.

Moral norm

(Strongly disagree [1] - Strongly agree [7])

I feel an obligation to choose a sustainable museum instead of a regular museum 
when deciding on museum travel.

Regardless of what other people do, because of my own values/principles I feel that I should behave in an environmentally friendly way while visiting a museum.

$\begin{array}{ll}\text { I feel that it is important to make museum environmentally sustainable, reducing } & .74\end{array}$ the harm to the environment.

I feel it is important that museum visitors behave in a sustainable way during their $\quad .99$ museum traveling.

Satisfaction with green product use

(Strongly disagree [1] - Strongly agree [7])

My overall experiences with environmentally friendly products are generally satisfactory.

Overall, I am often highly satisfied with eco-friendly products.

Overall, I am more frequently satisfied with products marked with green labels compared to non-marked products.

\section{Green trust}

(Strongly disagree [1] - Strongly agree [7])

I have confidence that the environmental performances of eco-friendly products are

reliable.

I feel that I can trust the environmental performances of eco-friendly products.

I think that products marked with green labels keep promises and commitment for environmental protection.

Frequency of past behavior for green product use

(Strongly disagree [1] - Strongly agree [7])

I have often used environmentally friendly products in the past one year.

I have frequently purchased products marked with green labels in the past one year.

Pro-environmental intention

(Strongly disagree [1] - Strongly agree [7])

I am willing to visit an environmentally responsible museum in the future.

I plan to visit an environmentally responsible museum in the future.

I will expend effort on visiting an environmentally responsible museum in the

future.

Note. The values (Lamda and composite reliability) were obtained/calculated on the results of the confirmatory factor analysis comprising all research variables (Goodness-of-fit statistics: $\chi^{2}=1515.28, d f$ $=683, \chi^{2} / d f=2.22, p<.001, \mathrm{RMSEA}=.053, \mathrm{CFI}=.92, \mathrm{IFI}=.93, \mathrm{TLI}=$ $.92) .{ }^{*}$ Reverse coded 